\title{
Evaluation of Nutritional Status of Children with Acute Lower Respiratory Tract Infection Mohammad Nagieb AboElfotoh ${ }^{1}$, Ehab Mahmoud Rasheed ${ }^{1}$, Samar Mahmoud Sharaf ${ }^{2}$, Noha Abdel Baset Tohamy*1
}

${ }^{1}$ Departments of Pediatric, ${ }^{2}$ Departments of Clinical Pathology - Faculty of Medicine, Zagazig University *Corresponding author: Noha Abdel Baset Tohamy; Mobile: (+20)01003220889; E-mail: bodytota2020@yahoo.com

\begin{abstract}
Background: Pediatric respiratory disease remains an important cause of morbidity in both developing and developed world. Several risk factors are associated with acute respiratory infection (ARIs), some of them are un-modifiable (e.g. age and sex of the child), while others are modifiable and these include nutritional and environmental modifiable risk factors (e.g. lack of breastfeeding and severe malnutrition).

Objective: This study was designed to evaluate nutritional status of children with acute lower respiratory tract infection.

Patients and methods: This study included 40 children, aged from 1 to 5 years suffering from acute lower respiratory tract infection (ALRI). The children were subjected to complete history, clinical examination and laboratory investigation as estimation of serum level of zinc and pre-albumin.

Results: In children with ALRI, there was non-significant difference between children with pneumonia, bronchitis and bronchopneumonia as regard breast feeding, supplementation, MAC, Zinc and pre-albumin, however, the difference between them was significant as regarding BMI and nutritional status.

Conclusion: The results of this study concluded that there is positive relation between nutritional status of child and acute LRTI. There was significant decrease in mortality and morbidity due to RTI after improvement of nutritional status of children. The level of zinc and pre-albumin were affected by nutritional status of children.

Keywords: Zinc, Prealbumin, Nutritional Status, Children, LRTI.
\end{abstract}

\section{INTRODUCTION}

Pediatric respiratory disease remains an important cause of morbidity in both developing and developed world. Pneumonia or ALRI cause over 2 million deaths annually among children younger than 5 years of age. Responsible for about $19 \%$ of all children deaths. Pneumonia is the leading cause of children mortality ${ }^{(\mathbf{1})}$. Improvements in nutrition are a keystone of current global efforts to reduce the burden of mortality and morbidity due to ALRIs among children living in developing countries ${ }^{(2)}$.

Clinical studies indicate that determination of the pre-albumin level may allow for earlier recognition of and intervention formal. Synthesis of pre-albumin increases above baseline levels within 48 hours of protein supplementation in children with severe protein calorie malnutrition and returns to normal levels within eight days. These observations and others led to the recommendation that prealbumin levels should rise $2 \mathrm{~g} / \mathrm{dL}(20 \mathrm{~g} / \mathrm{L})$ per day with adequate nutritional support ${ }^{(3)}$.

Zinc deficiency is widely prevalent in the developing areas of the world, which also have a high incidence of ALRI. Zinc deficiency has been a particular focus of attention because of its high frequency in developing countries and its debilitating effects on immune function ${ }^{(4)}$.

\section{AIM OF THE WORK}

The aim of our study was to evaluate nutritional status of children with acute lower respiratory tract infection.

\section{SUBJECTS AND METHODS}

- Type of the study: This was a cross sectional study.

- Study setting: Conducted in Pediatric Outpatient Clinics, Pediatric Department, Zagazig University Hospitals.

- Study period: From October 2017 to March 2018.

- Sample size: Total sample size included 40 children from 1 to 5years old.

- Study group: 40 children from 1 to 5 years old with ALRTI selected randomly from those attending the outpatient pediatric clinic.

- Consent: This study was ethically approved from Institutional Reviewer Board (IRB), in Faculty of Medicine, Zagazig University and consents from parents of children, participating in this research, were taken.

\section{Inclusion criteria:}

1. Age: $1-5$ years old children.

2. Sex: both sexes are included.

3. Children with acute lower respiratory tract infection.

Exclusion criteria:

1. Absence of informed consent.

2. Children with other chronic disease (renal disease-cardiac disease).

3. Children with gastrointestinal disease.

4. Children with total parenteral nutrition (TPN) in the previous month. 


\section{Operational design:}

1- A questionnaire interview for collection of personal data, sociodemographic data and complete history taking with particular emphasis on age, sex, initial clinical presentation and associated comorbidities.

2- Full clinical examinations including anthropometric measurements (BW, HT, and BMI) and vital signs (HR, BP and RR) were recorded.

\section{3- Laboratory investigations:}

- Measurement of serum zinc and pre-albumin levels.

- Complete blood count and C-reactive protein.

Estimation of serum level pre-albumin was done by ELISA technique, while serum level of zinc was done by colorimetric method.

\section{Ethical approval:}

The Ethical Review Board of the Faculty of Medicine, Zagazig University, approved this study.

\section{Statistical analysis}

Data were collected, tabulated and statistically analyzed using SPSS version 19. Continuous Quantitative variables were expressed as the mean \pm SD \& median (range). Categorical qualitative variables were expressed as absolute frequencies (number) \& relative frequencies (percentage). Continuous data were checked for normality by using Kolmogorv-Smirnov test.

One-way ANOVA test was used to compare more than two groups of normally distributed data. Kruskall-wallis test was also used to compare between more than two continuous not normally distributed data. Categorical data were compared using Chi-square test. Pearson correlation was used to determine correlation coefficient between continuous variables. All tests were two-sided and pvalue $\leq 0.05$ was considered statistically significant (S), p-value $<0.01$ was considered highly statistically significant (HS) and $\mathrm{p}$-value $\geq 0.05$ was considered statistically insignificant (NS).
RESULT

Table (1): Demographic data of the studied group

\begin{tabular}{|c|c|c|}
\hline Variable & \multicolumn{2}{|c|}{$\begin{array}{l}\text { Studied group } \\
\quad(n=40)\end{array}$} \\
\hline \multicolumn{3}{|l|}{ Age: } \\
\hline $\begin{array}{l}\text { Mean } \pm \text { SD } \\
\text { Range }\end{array}$ & \multicolumn{2}{|c|}{$\begin{array}{c}2.36 \pm 2.5 \\
1-4\end{array}$} \\
\hline & No & $\%$ \\
\hline \multicolumn{3}{|l|}{ Sex: } \\
\hline Female & 17 & 42.5 \\
\hline Male & 23 & 57.5 \\
\hline
\end{tabular}

This table showed that the age of the participants ranged between 1 and 4 years with mean of 2 years. More than half of them were males $(57.5 \%)$ and the remaining $42.5 \%$ were females.

Table (2): Anthropometric measurements of the studied group

\begin{tabular}{|l|c|}
\hline \multicolumn{1}{|c|}{ Variable } & $\begin{array}{c}\text { Studied group } \\
(\mathbf{n}=\mathbf{4 0})\end{array}$ \\
\hline Weight: $(\mathbf{K g})$ & $12.61 \pm 2.25$ \\
& $9-16.7$ \\
\hline Mean \pm SD & $88.4 \pm 8.45$ \\
Range & $73-105$ \\
\hline Height: (cm) & $16.2 \pm 2.56$ \\
\hline Mean \pm SD & $11.4-19.8$ \\
Range \\
\hline BMI: \\
\hline Mean \pm SD \\
Range \\
\hline Head circumference: \\
\hline Mean \pm SD \\
Range \\
\hline Mid arm circumference: \\
\hline Mean \pm SD \\
Range \\
\hline
\end{tabular}

This table showed that the mean weight of the studied group was $12.6 \mathrm{Kg}$, mean height was 88.4 $\mathrm{cm}$ and mean BMI was $16.2 \mathrm{~kg} / \mathrm{m}^{2}$. As regarding head and mid arm circumference, their mean were found to be 49.5 and 15.7 respectively.

Table (3): Comparison of clinical data among the studied groups

\begin{tabular}{|c|c|c|c|c|c|c|}
\hline \multirow{2}{*}{ Variable: } & \multicolumn{2}{|c|}{ Malnourished group $(n=22)$} & \multicolumn{2}{|c|}{ Normal group $(n=18)$} & \multirow{2}{*}{$\chi^{2}$} & \multirow{2}{*}{$\mathbf{P}$} \\
\hline & No: & $\%$ & No: & $\%$ & & \\
\hline \multicolumn{7}{|l|}{ Breast feeding: } \\
\hline Yes: & 14 & 63.6 & 10 & 45.4 & \multirow{2}{*}{3.252} & 0.071 \\
\hline No: & 8 & 36.7 & 8 & 36.6 & & (NS) \\
\hline \multicolumn{7}{|c|}{ Supplementation: } \\
\hline No: & 12 & 54.5 & 14 & 77.8 & \multirow{4}{*}{4.123} & \multirow{4}{*}{$\begin{array}{c}0.248 \\
\text { (NS) }\end{array}$} \\
\hline Vitamin D: & 5 & 22.7 & 4 & 22.2 & & \\
\hline Zinc: & 2 & 9.1 & 0 & 0 & & \\
\hline Zinc and vit $\mathrm{D}$ : & 3 & 13.6 & 0 & 0 & & \\
\hline \multicolumn{7}{|l|}{ Appetite: } \\
\hline Decreased: & 19 & 86.3 & 6 & 33.3 & \multirow{2}{*}{11.88} & 0.0005 \\
\hline Normal: & 3 & 13.7 & 12 & 66.7 & & $(\mathrm{~S})$ \\
\hline
\end{tabular}

This table showed that there was non-significant difference between both groups as regarding breast feeding and supplementation, however the difference between them was significant in appetite pattern with $86.3 \%$ of malnourished infants had decreased appetite compared to $33.3 \%$ in the normal group. 
Table (4): Comparison of Laboratory data among the studied groups

\begin{tabular}{|c|c|c|c|c|}
\hline Variable & $\begin{array}{l}\text { Malnourished group } \\
\quad(\mathrm{n}=\mathbf{2 2})\end{array}$ & $\begin{array}{c}\text { Normal } \\
\text { group } \\
(\mathbf{n}=18)\end{array}$ & test & $P$ value \\
\hline \multicolumn{5}{|l|}{ Zinc: } \\
\hline $\begin{array}{l}\text { Mean } \pm \text { SD } \\
\text { Median } \\
\text { Range }\end{array}$ & $\begin{array}{c}220.3 \pm 331.5 \\
78.3 \\
16.3-1038.3\end{array}$ & $\begin{array}{c}211 \pm 174.2 \\
156.8 \\
33.6-742.7\end{array}$ & 0.107 & $\begin{array}{l}0.916 \\
\text { (NS) }\end{array}$ \\
\hline \multicolumn{5}{|l|}{ Pre-albumin: } \\
\hline $\begin{array}{l}\text { Mean } \pm \text { SD } \\
\text { Median } \\
\text { Range }\end{array}$ & $\begin{array}{c}712.5 \pm 567.7 \\
505 \\
86-1800\end{array}$ & $\begin{array}{c}654 \pm 412.5 \\
645 \\
95-1400\end{array}$ & 0.294 & $\begin{array}{l}0.717 \\
\text { (NS) }\end{array}$ \\
\hline
\end{tabular}

Test: Mann-Whitney test.

This table showed that there was non-significant difference between the studied groups as regarding zinc and pre-albumin. It was noticed that zinc and pre-albumin levels were lower in malnourished when compared to the normal group (78.3 and 505 versus 505 and 645 respectively).

Table (5): Comparison of different clinical data among the studied groups

\begin{tabular}{|c|c|c|c|c|c|c|c|c|}
\hline \multirow[t]{2}{*}{ Variable } & \multicolumn{2}{|c|}{$\begin{array}{l}\text { Pneumonia } \\
\quad(n=13)\end{array}$} & \multicolumn{2}{|c|}{$\begin{array}{l}\text { Broncho-pneumonia } \\
\qquad(\mathrm{n}=11)\end{array}$} & \multicolumn{2}{|c|}{$\begin{array}{l}\text { Bronchiolitis } \\
\quad(\mathrm{n}=16)\end{array}$} & \multirow[t]{2}{*}{$\chi^{2}$} & \multirow[t]{2}{*}{$\mathbf{P}$} \\
\hline & No. & $\%$ & No. & $\%$ & No. & $\%$ & & \\
\hline \multicolumn{9}{|l|}{ Breast feeding: } \\
\hline Yes: & 10 & 76.9 & 5 & 45.5 & 10 & 62.5 & \multirow{2}{*}{6.746} & 0.150 \\
\hline No: & 3 & 23.1 & 6 & 54.5 & 6 & 37.5 & & (NS) \\
\hline \multicolumn{9}{|l|}{ Supplement: } \\
\hline No: & 10 & 76.9 & 8 & 72.7 & 7 & 43.8 & \multirow{4}{*}{5.623} & \multirow{4}{*}{$\begin{array}{r}0.467 \\
(\mathrm{NS})\end{array}$} \\
\hline Vitamin D: & 2 & 15.4 & 2 & 18.2 & 5 & 31.3 & & \\
\hline Zinc: & 0 & 0 & 0 & 0 & 2 & 12.5 & & \\
\hline Zinc and vit D: & 1 & 7.7 & 1 & 9.1 & 2 & 12.5 & & \\
\hline \multicolumn{9}{|c|}{ Nutrition status: } \\
\hline Malnourished: & 9 & 69.2 & 10 & 90.9 & 3 & 18.8 & \multirow{2}{*}{15.29} & \multirow{2}{*}{$\begin{array}{l}0.004 \\
(\mathrm{~S})\end{array}$} \\
\hline Normal: & 4 & 30.8 & 1 & 9.1 & 13 & 81.2 & & \\
\hline Variable & \multicolumn{2}{|c|}{$\begin{array}{l}\text { Pneumonia } \\
(\mathbf{n}=13)\end{array}$} & \multicolumn{2}{|c|}{$\begin{array}{c}\text { Broncho-pneumonia } \\
\quad(\mathbf{n}=11)\end{array}$} & \multicolumn{2}{|c|}{$\begin{array}{l}\text { Bronchiolitis } \\
\quad(n=16)\end{array}$} & Test & $\mathbf{P}$ \\
\hline \multicolumn{9}{|l|}{ BMI: } \\
\hline Mean \pm SD & \multirow{2}{*}{\multicolumn{2}{|c|}{$\begin{array}{l}17.6 \pm 0.91 \\
16.4-19.8\end{array}$}} & & 0.75 & \multirow{2}{*}{\multicolumn{2}{|c|}{$\begin{array}{l}18.7 \pm 0.81 \\
17.4-19.8\end{array}$}} & \multirow{2}{*}{$114.1^{*}$} & \multirow{2}{*}{$\begin{array}{l}<0.001 \\
\text { (HS) }\end{array}$} \\
\hline Range & & & & 19.8 & & & & \\
\hline \multicolumn{9}{|l|}{ MAC: } \\
\hline Mean \pm SD & \multirow{2}{*}{\multicolumn{2}{|c|}{$\begin{array}{c}15.1 \pm 0.74 \\
14-16.4\end{array}$}} & & 1.15 & \multirow{2}{*}{\multicolumn{2}{|c|}{$\begin{array}{l}15.9 \pm 1.01 \\
13.5-17.5\end{array}$}} & \multirow{2}{*}{$2.504 *$} & \multirow{2}{*}{$\begin{array}{c}0.096 \\
\text { (NS) }\end{array}$} \\
\hline Range & & & & 17 & & & & \\
\hline \multicolumn{9}{|l|}{ Zinc: } \\
\hline Mean \pm SD & \multirow{3}{*}{\multicolumn{2}{|c|}{$\begin{array}{c}212 \pm 157.6 \\
157.7 \\
45.4-604 \\
\end{array}$}} & & 365 & \multirow{3}{*}{\multicolumn{2}{|c|}{$\begin{array}{c}187 \pm 186.3 \\
112.5 \\
16.3-742.7\end{array}$}} & \multirow{3}{*}{$1.557 \#$} & \\
\hline Median & & & & & & & & 0.459 \\
\hline Range & & & & 1038 & & & & \\
\hline Pre-albumin: & & & & & & & & \\
\hline Mean \pm SD & & 66.6 & & 574 & & 461 & & \\
\hline Median & & & & & & & 1.392\# & $\begin{array}{c}0.498 \\
\text { (NS) }\end{array}$ \\
\hline Range & & & & 800 & & 600 & & \\
\hline
\end{tabular}

*: ANOVA test.

\#: Kruskall-wallis test.

This table showed that there was non-significant difference between the three groups as regarding breast feeding, supplementation, MAC, zinc and pre-albumin. However, the difference between them was significant as regarding BMI and nutritional status. 
Table (6): Correlation between body mass index and different parameters among the studied group

\begin{tabular}{|l|c|c|}
\hline \multirow{2}{*}{ Variable } & \multicolumn{2}{|c|}{ BMI } \\
\cline { 2 - 3 } & $\mathbf{r}$ & $\mathbf{p}$ \\
\hline Zinc: & 0.026 & 0.873 \\
\hline Albumin: & 0.248 & 0.075 \\
\hline CRP: & 0.196 & 0.300 \\
\hline Head circumference: & 0.813 & $<0.001^{* *}$ \\
\hline Weaning age: & -0.253 & 0.116 \\
\hline
\end{tabular}

This table showed that there was non-significant positive correlation between BMI and zinc, albumin. However, the correlation was significant strong positive between BMI and head circumference.

\section{DISCUSSION}

Acute lower respiratory tract infections are ranked among the first five leading causes of mortality in children in developing countries. Mortality due to ALRI was $18 \%$ of total under five years mortality rates, which were 61 per $1,000<5$ yrs population. Half of children with symptoms of ARI were taken to a health facility or health provider. Seven percent of children with ARI symptoms received antibiotics ${ }^{(5)}$.

The excess of morbidity and mortality rates from acute lower respiratory tract infections in the developing world indicate that several risk factors could be responsible. In developing countries malnutrition, lack of breast feeding, lack of immunization and overcrowding were reported as the usual risk factors of acute lower respiratory tract infections ${ }^{(6)}$.

Our study was conducted on forty children with ALRTI who were examined and diagnosed clinically according to WHO ${ }^{(7)}$. All patients were subjected to thorough history taking, clinical assessment of respiratory infections, physical examination (both general and systemic examination particularly chest) and laboratory investigations including chest X-ray, measurement of zinc and pre-albumin levels, complete blood count and C-reactive protein.

Our study showed that the age of the participants ranged between 1 and 4 years with mean of 2 years old. More than half of them were males $(57.5 \%)$ and the remaining $42.5 \%$ were females. In another study, compared to females, males seemed to suffer more commonly from most types of RTI ${ }^{(8)}$. Tsai $\boldsymbol{e t}$ al. ${ }^{(9)}$ demonstrated a higher incidence of respiratory tract infection in boys. Goel et al. ${ }^{(10)}$ and Silfeler et al. ${ }^{(11)}$ found that respiratory tract infections are common in young children, decrease in frequency with age, and predominate in boys. It also agrees with Lin et al. ${ }^{(12)}$ who found that most of the respiratory viral infections are common in male children. Muenchhoff and Goulder ${ }^{(13)}$ found that females are more commonly affected with infections of the upper respiratory tract, specifically sinusitis, tonsillitis, and otitis externa, while males are more commonly affected with otitis media, croup and most important lower RTIs. On the other hand, Montasser et al. ${ }^{(14)}$ found that female patients were more infected with ARTI than males in Egypt.
Our study showed that the mean weight of the studied group was $12.6 \mathrm{Kg}$, mean height was $88.4 \mathrm{~cm}$, and mean BMI was 16.2. As regarding head and midarm circumference, their mean were found to be 49.5 and 15.7 respectively. Martorell ${ }^{(15)}$ reported that LRTI was significantly associated with decreased weight gain. Heywood ${ }^{(16)}$ found strong relationships between all three indices of nutritional status and mortality in children with ALRTI aged 6-30 months. Tomkins et al. ${ }^{(17)}$ found no relationship between prevalence of any respiratory illness and anthropometric indices.

In our study, $62.5 \%$ of the studied participants were breastfed and $62.5 \%$ had normal appetite. The mean age of weaning was 5 months with range between 3 and 6 months. Kaymaz et al. (18) investigated the relationship between parental perception of their child's body measurements and appetite. They found that perception of the parents of their children's growth is influenced by many factors and usually does not reflect the facts. The majority of the children with poor appetite were in normal weight range according to BMI percentile. Nevertheless, nearly one third of the children were underweight, a fact that should not be ignored. Abdul Raheem et al. (19) measured associations between feeding methods and ARTIs in a cohort study of 6 months. They found that the partial, predominant and exclusive breastfeeding rates at 1 month were 98.9, 67.6 and $26.9 \%$, respectively. The risk of acquiring ARTIs is significantly reduced when the infants were predominantly breastfed for 3 months and 6 months. The risk of getting diarrhoea is significantly reduced even when the babies were partially breastfed for 6 months. They demonstrated that the risk lowers with longer duration of breastfeeding.

In our study, Zinc level ranged between 16.3 and $1038 \mu \mathrm{g} / \mathrm{dl}$ with mean of 214.3 and that of prealbumin mean was $674.5 \mu \mathrm{g} / \mathrm{dl}$. Roth et al. (20) concluded that zinc supplementation in zinc-deficient populations prevents about one-quarter of episodes of ALRI, which may translate into a modest reduction in ALRI mortality. Breastfeeding promotion reduces ALRI morbidity, while iron supplementation alone did not reduce ALRI incidence. Also, vitamin A supplementation beyond the neonatal period did not reduce ALRI incidence or mortality. Reddy et al. ${ }^{(1)}$ identified various nutritional risk factors and serum 
zinc level for ALRI in children aged 6 months to $5 \mathrm{yr}$. The significant nutritional risk factors were malnutrition, anaemia and low serum zinc level. Sociodemographic factors like partial immunization status and SES which were taken into study didn't have any significant association with ALRI. The interesting fact is nutritional factors, which were found to be significant in this study are actually either preventable or curable.

Regarding pre-albumin, according to the Academy's Evidence Analysis Library, serum proteins such as albumin and pre-albumin are not included as defining characteristics of malnutrition because evidence analysis showed that serum levels of these proteins did not change in response to changes in nutrient intake ${ }^{(21)}$.

Our study showed that $45 \%$ of the studied participants were normal, while the remaining $55 \%$ were malnourished. Chalabi (22) studied the relationship between nutritional status and ARI among young children attending a teaching hospital in Erbil, Iraq. Children admitted to hospital with a diagnosis of ARI over a 4-month period were compared to a control group without ARI. Significantly more ARI cases were male and the mean age was lower. Weight and height were lower in the ARI group but there was no significant difference in weight-for-age or in height-for-age. They concluded that most cases of ARI in this hospital in Erbil occurred below the age of 1 year and boys were more prone to ARI than girls. Malnutrition significantly increase the risk of having ARI among children $<5$ years of age.

In our study, there was non-significant difference between both groups as regarding breastfeeding, supplementation, zinc and pre-albumin. However, the difference between them was significant in appetite pattern where $86.3 \%$ of malnourished infants had decreased appetite compared to $33.3 \%$ in the normal group.

Our study showed that the commonest diagnosis among the studied group was bronchiolitis (40\%), followed by pneumonia (32.5\%) and $27.5 \%$ of them had bronchopneumonia. Mishra et al. ${ }^{(23)}$ diagnosed $56 \%$ (60) as cases of severe pneumonia, 35\% (37) as pneumonia and 9\% (10) were very severe pneumonia.

According to WHO, pneumonia is the single largest cause of death in children worldwide. Every year, it kills an estimated 1.2 million children under the age of five years, accounting for $18 \%$ of all deaths of children under five years worldwide. More than $99 \%$ of all pneumonia deaths occurring in developing countries, and three-quarters take place in just 15 countries. The annual incidence of pneumonia in developing countries is 10-12 times higher than in developed countries that is $10-20 / 100$. However, incidences exceeding 50/100 occur with high prevalence's of malnutrition and high HIV infection rates in children. More than $95 \%$ of all new cases of pneumonia in children, less than 5 years occur in developing countries, due to increased prevalence of under-nutrition, which is implicated in 53\% of all deaths among children less than 5 years ${ }^{(23)}$.

Our study found that there was non-significant difference between the three groups as regarding breast feeding, supplementation, MAC, Zinc and prealbumin, however, the difference between them was significant as regarding BMI and nutritional status. Also, there was non-significant positive correlation between BMI, zinc, pre-albumin. However, the correlation was significantly strong positive between BMI and head circumference.

Prajapati and Talsani ${ }^{(24)}$ reported highest risk of death from ALRI due to malnutrition among those below two years of age. It is well known that malnourished children have defective cell mediated immunity secondary to thymolymphocytic depletion leading to severe gram negative infections and sepsis. They may also have qualitatively abnormal immunoglobins, and impairment of key enzymes involved in bactericidal action of leucocytes, thereby making them all the time to be more prone to infections. Mishra et al. ${ }^{(23)}$ concluded that wasted children were more prone to suffer from ALRI as compared to stunted children.

\section{CONCLUSION}

There is positive relation between nutritional status of children and acute LRTI. There is significant decrease in mortality and morbidity due to RTI after improvement of nutritional status of children. The level of zinc and pre-albumin were affected by nutritional status of child.

These results add to the growing attention to the role of nutritional status in the susceptibility to infection-related illness in children.

Implementation and rigorous evaluation of multicomponent nutritional intervention programs should be a high priority to reduce the incidence and mortality associated with severe ALRI, as well as the overall disease burden that persists among children in developing countries.

Acknowledgement: The authors are grateful for the patients without them this study would not have been done.

Conflict of interest: The authors declare no conflict of interest

Funding sources: The authors have no funding to report.

\section{REFERENCES}

1. Reddy MNL, Hegde S, Sadashi V (2014): A study of nutritional risk factors and plasma zinc levels in children with acute lower respiratory infections. Int $\mathbf{J}$ Pharm Bio Sci., 4 (2): 117-120.

2. Beck FK, Rosenthal TC (2002): Prealbumin A Marker for Nutritional Evaluation. Am Fam Physician, 65 (8): 1575-1578. 
3. Black RE (2003): Zinc deficiency, infectious disease and mortality in the developing world. J Nutr., 133: 1485-1489.

4. Prasad DP, Chandrashekhar HG, Madhavi VR (2010): Study of Risk Factors of Acute Respiratory Infection (ARI): in Under-fives in Solapur. National Journal of Community Medicine, 2 (1): 64-67.

5. Nepal Demographic and Health Survey (2011): Population Division, Ministry of Health and Population Government of Nepal Kathmandu. https://dhsprogram.com/pubs/pdf/FR257/FR257\%5B1 3April2012\%5D.pdf

6. Yadav S, Khinchi Y, Pan A et al. (2013): Risk Factors for Acute Respiratory Infections in Hopsitalized Under Five Children in Centre Nepal. J Nepal Paediatr Soc., 33 (1): 39-44.

7. World Health Organization (WHO) (2005): Department of Child and Adolescent Health. Handbook: IMCI Integrated Management of Childhood Illness. www. awhqlibdoc. WHO, int/ publications/924.

8. Falagas ME, Mourtzoukou EG, Vardakas KZ (2007): Sex differences in the incidence and severity of respiratory tract infections. Respiratory Medicine, 101 (9): $1845-63$.

9. Tsai H, Kuo P, Liu C et al. (2001): Respiratory Viral Infections among Pediatric Inpatients and Outpatients in Taiwan from 1997 to 1999. J Clin Microbiol., 39 (1): 111-18.

10. Goel K, Ahmad S, Agarwal G et al. (2012): A cross sectional study on prevalence of acute respiratory infections (ARI): in under-five children of Meerut District, India. J Comm Med Health Educ., 2: 176-179.

11. Silfeler I, Tanidir IC, Arica V (2012): Risk factors for lower respiratory tract infections in children. Pak $\mathbf{J}$ Med Sci., 28 (3): 488-91.

12. Lin TY, Huang YC, Ning HC et al. (2004): Surveillance of respiratory viral infections among pediatric outpatients in northern Taiwan. J Clin Virol., 30 (1): 81-85.

13. Muenchhoff M, Goulder JR (2014): Sex Differences in the Manifestations of Infectious Diseases. J Infect Dis., 209 (3): 120-26.

14. Montasser N, Helal R, Rezq R (2012): Assessment and classification of acute respiratory tract infections among Egyptian rural children. BJMMR., 2 (2): 216227.
15. Martorell R (1980): Interrelationships between diet, infectious disease, and nutritional status. Human Population Biology: A Transdisciplinary Science. https://books.google.com.eg/books?

16. Heywood PF (1986): Nutritional status as a risk factor for mortality in children in the highlands of Papua New Guinea. In Proceedings of the Thirteenth International Congress of Nutrition. London, John Libbey, Pp: 103106.

17. Tomkins AM, Dunn DT, Hayes RJ (1989): Nutritional status and risk of morbidity among young Gambian children allowing for social and environmental factors. Trans R Soc Trop Med Hyg., 83: 282-287.

18. Kaymaz N, Bulur N, Yildirim S et al. (2015): Poor appetite in school children: Is it a false perception of parents? The Journal of Pediatric Research, 2 (1): 116.

19. Abdul Raheem R, Binns CW, Chih HJ (2017): Protective effects of breastfeeding against acute respiratory tract infections and diarrhea: Findings of a cohort study. Journal of Paediatrics and Child Health, 53: 271-276

20. Roth DE, Caulfield LE, Ezzatib M et al. (2008): Acute lower respiratory infections in childhood: Opportunities for reducing the global burden through nutritional interventions. Bulletin of the World Health Organization, 86: 356-364.

21. White JV, Guenter P, Jensen G et al. (2012): Consensus Statement of the Academy of Nutrition and Dietetics/American Society for Parenteral and Enteral Nutrition: Characteristics recommended for identification and documentation of adult malnutrition (undernutrition). J Acad Nutr Diet, 112 (5): 730-738.

22. Chalabi DA (2013): Acute respiratory infection and malnutrition among children below 5 years of age in Erbil governorate, Iraq. Eastern Mediterranean Health Journal, 19 (1): 66-70.

23. Mishra P, Parajuli J, Acharya N et al. (2014): Malnutrition as a modifiable risk factor of lower respiratory tract infections among under five children. Journal of Nepalgunj Medical College, 12 (2): 2-5.

24. Prajapati B, Talsani SK (2011): A study on prevalence of acute respiratory tract infections (ARI): in under five children in urban and rural communities of Ahmedabad district, Gujarat. National Journal of Community Medicine, 2 (2): 255-59. 